\title{
Ibn Khaldûn's Perspective About Equilibrium of Price in Muqaddimah Book
}

\author{
Siti Khoirunnisa' \\ Sharia Faculty Maulana Malik Ibrahim State Islamic University of Malang \\ nisakhoir48@yahoo.com
}

\begin{abstract}
:
The purpose of the research was to understand about Ibn Khaldûn's perspective about equilibrium of price in his era and about the factors which influence equilibrium of price and to know about the similarities and the differences between Ibn Khaldûn's equilibrium of price and contemporary equilibrium of price. This research was Qualitative research. The approach used in this research was conceptual approach. It was studying about social phenomenon which has been happen in Ibn Khaldûn's era within use the concept of him in muqaddimah book. From this research could be seen that the equilibrium of price depends on Ibn Khaldûn's perspective will be happen when the quantity of demand as same as the quantity of supply of goods. It is related to the available of goods, and the situation of development of city. It also become the concept in the economic modern when the supply and demand of product should influence to the equilibrium of price. And there were some factors influenced the equilibrium of price in his era. The capability of workers and the needed of employer, the condition of city and the population there, the additional cost of goods because of taxation, etc.
\end{abstract}

Tujuan dari penelitian ini adalah untuk memahami tentang perspektif Ibn Khaldun tentang keseimbangan harga di jamannya dan tentang faktor-faktor yang mempengaruhi keseimbangan harga dan mengetahui tentang persamaan dan perbedaan antara ekuilibrium Ibn Khaldun harga dan keseimbangan kontemporer harga. Penelitian ini merupakan penelitian kualitatif. Pendekatan yang digunakan dalam penelitian ini adalah pendekatan konseptual. Sedang mempelajari tentang fenomena sosial yang telah terjadi di era Ibn Khaldun dalam penggunaan konsep dirinya dalam buku Muqaddimah. Dari penelitian ini dapat dilihat bahwa keseimbangan harga tergantung pada perspektif Ibn Khaldun akan terjadi ketika jumlah permintaan sebagai sama dengan kuantitas pasokan barang. Hal ini terkait dengan tersedia barang, dan situasi dari perkembangan kota. Hal ini juga menjadi konsep dalam ekonomi modern ketika pasokan dan permintaan produk harus berpengaruh terhadap keseimbangan harga. Dan ada beberapa faktor yang mempengaruhi keseimbangan harga di jamannya. Kemampuan pekerja dan diperlukan dari majikan, kondisi kota dan penduduk di sana, biaya tambahan barang karena perpajakan, dll

Key Words: Equilibrium of Price; Muqaddimah; ibn Khaldun 


\section{Introduction}

Many people in the world state that almost of economic theories are famous from western economic thinker, such as Adam Smith who is popular with his book with the tittle "The Wealth of Nation", Thomas Robert Malthus which is famous with many books as his magnum opus but the most popular book is "Principles of Population". ${ }^{1}$ There is also the economic thinker namely David Ricardo with his book by the title is "The Principles of Political Economy and Taxation", John Stuarte Mill who is famous with the book "Principles of Political Economy With Some of Their Applications to Social Philosophy". They are the thinkers of capitalism side. Beside that there is also the thinker of socialism side, namely Karl Marx who wrote the book with the tittle Manifesto Komunis. It has been known that the economic system in the world is powered by the two systems, capitalism system and socialism system. Let us see to the phenomenon of economics system that ever implemented in the world. There are capitalism system which appreciate more to the free labor with the spirit of individual competition between the capital owner without care to the accumulate wealth, accumulate capital, and it does not care to the financing for something useless or does not give the social values any more. The capitalism views are freedom of doing economic activities, freedom of using the nature resource without the supervision of the country and the government, because there will the invisible hands to bring the balance. ${ }^{2}$ Then the impact of implementing this capitalism system is unjustifiable for the poor, because the wealth is around the capital owner or rich people. So, there is unbalancing life in the world. Beside the capitalism system, there is also the socialism system which was born because of the poverty of laborer and farmer as the effect of industry revolution in Europe. The socialism system invites every people to leave the individual own of the production tools which support the capitalism system and argue that there should has the community powered lead by the country in economics activities, then the prosperity of every people is relatively same. ${ }^{3}$

So, the big question is about the position of Islamic economics today. As the prophet's teaching, Islamic economics should be moderate system between the capitalism which will give more benefits to rich people and pressure the poor people, or socialism economical concept which will pressure the economic access of rich people and will give more benefit to the government. Then, Islamic economics rises as the solution with the four concepts. The prohibition of interest, the implementation of zakat, shadaqah, and waqaf, the production and consuming allowed (halâl) things, and forbidding of wasting. The fundamental concepts below are increased as well as the increasing of Islamic economics concepts in classical era which designed by the classical moslem thinkers, such as Abu Yusuf, Ibn Taimiyah, Al- Syaibani, Ibn Khaldûn, etc. The Islamic economic concept is developing today, there are so many Islamic economic product that rise in the world. Beginning from sharia banking system, Islamic insurance system, Islamic guarantee system, etc. Actually, all of the products are some parts of Islamic economics developing in the modern era. But, the reality said that Islamic economics development is still live around the capitalism, because the practice shows that actually the improvement of Islamic economics just effect to some aspects, such as banking system, insurance system, guarantee system that actually just keep the wealth around the capital owner. How about the distribution of prosperity aspect which should be reached by Islam. It is still becomes the big

\footnotetext{
${ }^{1}$ Deliarnov, Perkembangan Pemikiran Ekonomi (Jakarta: Raja Grafindo Persada, 2007), 48.

${ }^{2}$ Aam Slamet Rusydiana et al., Ekonomi Islam Subtantif (Bogor: Gaung Persada Press, 2009), 38.

${ }^{3}$ Rusydiana et al., Ekonomi Islam, 39.
}

Jurisdictie: Jurnal Hukum dan Syariah Vol. 6 No. 1 Tahun 2015 
problem of Islamic word nowadays. Then, the author assumed that if Muslim wants to improve the Islamic economics system, Muslim and all of people should understand about the Islamic economics concept which arranged in their history. In the beginning of this part, the writer has told about some of the pioneer of western economics concept.

The people in the world should know that there are many Islamic thinkers who expert in economic and created many economics theories such as Abu Yusuf, Ibn Taimiyah, Al- Syaibani, Ibn Khaldûn ,etc. Abu Yusuf is famous with the book Kitab al-Kharaj (the book about the taxation). Ibn Taimiyah is famous with his magnum opus Majmu' Fatâwâ Syaikh alIslam. AlSyaibani wrote $a l$ - Kasb which explains about the production activity in Islam. Beside that there was Ibn Khaldûn who is popular with his book namely Muqaddimah. This article would like to explain about the economic perspective of Ibn Khaldûn, especially on his book Muqaddimah. With understanding about the perspective of Ibn Khaldûn as the classical moslem economics thinker, hopefully the improvement of Islamic economics will run well and it spreads out around the world. The economic perspective develops day by day, so the increasing of that should be observed. Before knowing about the shape of perspective, we should know where the perspective comes from and who is the founder of the perspective. The perspective of Ibn Khaldûn builds the economic perspective in the world. It also becomes the reference of another concept that born from other thinkers. In the social side, this article will develop the understanding about the existence of Islamic value written in Muqaddimah book as a shape of the economic perspective from Ibn Khaldûn.

\section{Reseach Methods}

Research method is the way to do something with using the think seriously to get the purpose by implementing some ways such as searching, writing, arranging, analyzing until writing the report. ${ }^{4}$ This kind of this research is literary study, because this research focuses to explain and understand about Ibn Khaldûn's perspective especially about equilibrium price in his book. Depend on the research method, this research is qualitative research. Qualitative research is the research which has the meaning to understand the equilibrium done by the subject of research, for example based on the behavior, perspective, motivation, the action holistically. It uses the description way in word phrases and language, in the special context with some methods. ${ }^{5}$ This research uses conceptual approach because it will understand about the concept which build from the perspective about equilibrium price which assumed by Ibn Khaldûn in Muqaddimah book. This research also uses the philosophical approach which focus on economic concept by Ibn Khaldûn from philosophy side. This philosophical approach does not go far from the history which was built by Ibn Khaldûn in his writing Muqaddimah book, because almost of the explanation in Muqaddimah arranged by the story which is completed by many aspects of life, such as economics aspect, sociological aspect, political aspect, society aspect, and historical aspect. This research uses secondary data. In the literary research, the data used is secondary data, it is the data which is gotten from the written documents, the books which have related to the research's object, some results of research, such as thesis or another research report, ${ }^{6}$ especially for this research is the material in Muqaddimmah book. Beside that the writer will use the complementary books which discuss about the economic perspective from another thinkers.

\footnotetext{
${ }^{4}$ Cholid Narbuko and Abu Achmadi, Metodologi Penelitian (Jakarta: Bumi Aksara, 2003), 1.

${ }^{5}$ Lexy J Moleong, Metodologi Penelitian Kualitatif. (Bandung: Remaja Rosdakarya, 2011), 6.

${ }^{6}$ Zainuddin Ali, Metode Penelitian Hukum (Jakarta: Sinar Grafika, 2011), 106.

Jurisdictie: Jurnal Hukum dan Syariah Vol. 6 No. 1 Tahun 2015
} 


\section{Result and Discussion}

\section{The Equilibrium Price Depend On Ibn Khaldûn 's Perspective}

One of the classical Muslim thinker who explain about the market and the price is Ibn Khaldûn. He is a man who called by Schumpeter in the two places of his book entitled "History of Economic Analysis" although it does not related to his thinking in economical problems. ${ }^{7}$ In Muqaddimah book, Ibn Khaldûn wrote a chapter specifically with the title "The Prices in The Town". This title is written in the fourth chapter in Muqaddimah book. He told about the condition of price in his era. In the beginning of his explanation, Ibn Khaldûn divided the kind of human's necessity. There are three main necessity of people in the world. There are: primary necessity, secondary necessity, and tertiary necessity. He told that the primary necessity are the main food, such as wheat flour, the vegetables, the onion, and others. He continued the explanation about the secondary necessity and tertiary necessity. He took the example of secondary necessity such as the side dish, fruits, clothes, vehicles, crafts, buildings, etc. Actually, the kind of necessity influences the price of each goods. Beside that the number of population and the development of region also give important influence to the price of every goods. ${ }^{8}$ Ibn Khaldûn was also discussing the concept of demand. He said that crafts improve and increase when the demand for their products increases.

The reason for this is that man will not give his labor free of charge, for it is his source of livelihood and gain - indeed, his only source of profit throughout his life. Consequently he will only direct it towards those things which have value in his town in order to make profit. And when a craft is the object of demand, attracting more expenditure on the consumers side, it becomes like a commodity which, being in demand, is brought for sale in larger quantities. Therefore, the people of that city will try to learn (the skills necessity for) that craft in order to make their livelihood from it. However, should the craft not be in demand, its sales will fall and there will be no attempt to learn it. It will be then neglected and forgotten. This is the meaning of the reported saying of Caliph Ali bin Abi Thâlib: "the worth of every man lies in his skill". That is, the craft which that man has mastered is the measure of his value, or rather the value of his labor which is the source of his livelihood. In this regard, he again included the concept of labor value, which is measured, according to our analysis, from the labor's skill in mastering and producing certain product.

Ibn Khaldûn also included state demand on the craft as another factor creating demand, and the goods demanded by the state enjoy the highest sales. The state, according to him, is the greatest market spending on things without too much calculation. In his book, Ibn Khaldûn explained that the price of goods in the town can be cheap or expensive. When the development of city is good, the city would have many population there, so the price of primary necessity will be cheap, but the price of secondary and tertiary, such as the side dish, fruits, clothes, vehicles will be increased or it should be expensive. When, the population of city is little and the development of the city is low so the price of primary necessity will be expensive and the price of secondary necessity and tertiary necessity will be cheap. That condition happen because of the primary necessity is should be completed. Logically, everyone should fulfill his necessity, because people don't want to neglect his primary necessity which is related to his life. He does not just fulfill his own food or drink or other necessity, but he also fulfill it for his family. ${ }^{9}$

\footnotetext{
${ }^{7}$ Muhamad, Ekonomi Mikro Dalam Perspektif Islam (Yogyakarta: BPFE-Yogyakarta, 2004), 361.

${ }^{8}$ Ibn Khaldûn, Muqaddimah Ibn Khaldûn (Beirut: Dâr al- Kutub al-'Ilmiyyah, 2009), 286.

${ }^{9}$ Khaldûn, Muqaddimah, 286.

Jurisdictie: Jurnal Hukum dan Syariah Vol. 6 No. 1 Tahun 2015
} 
Because of fulfilling the necessity, the distribution of selling that goods is relatively same. The people who take the primary necessity will take it more than they need. So, the primary necessity will be available more than the needed of the city. Then the price will be cheap exactly. The opposite condition will be happen if there is the disaster in that city. Then, the society will collect the primary necessity because of they are worry. It happens because they feel afraid to face the limited condition of goods. Then the price of goods will be expensive. ${ }^{10}$

In the other situation, it will be happen the different condition. The secondary and tertiary necessity such as the side dish, and fruits or other necessity will not be the same in the distribution of selling the goods, then not all of the society in the city will buy it. It is because of the limitation of their ability for buying it. When the development of city is increased, the luxury goods will be spread out around the city. The people will effort to have the luxury goods as long as they can buy it. The ability of buying of every person is different, it depends to their economic situation. Then, the effect is the available of goods is limited. Because of that limitation, many people supply it, although the number of goods is very limited. Then, the people who want to buy it should be fight it with other people. ${ }^{11}$ From that statement of Ibn Khaldûn , the writer state that actually the equilibrium price will be implemented when the quantity of demand as same as the quantity of supply of goods. It is related to the available of goods, and the situation of development of city. It also become the concept in the economic modern when the supply and demand of product should influence to the equilibrium of price.

In the law of demand, the consumer will do rationally, that is the consumer will increase his buying when the price is lower or decreased, he will decrease his buying when the price is increase or upper. It will happen to the law of supply, the seller or the producer will do rationally, that is will making his selling more when the price is increase, and he will decrease his selling when the price is decreased. From both of reality bellows, the next problem is how to make the exchange happen. The answer is the exchange will be happen when the seller hold out to the price he decided or the price which give him many profits. Beside that the buyer also want to have the price which does not make him loss. The process which is happen to both of the society wants will arrive to an agreement of price between the seller and the buyer. It happen when the buyer gives his selling good with some certain price, and the consumer want to pay the certain price. The price agreement which is happen bellow then takes the name as the equilibrium price. ${ }^{12}$ Ibn Khaldûn explains about the mechanism of supply and demand in determining the equilibrium price, exactly. In specific part, he also explains about the influence of the competition between the consumer to get the goods in the demand side. After that, in the supply side, he explains about the influence of increasing the production fee because of taxation and other cause from that city. ${ }^{13}$ The Ibn Khaldûn 's perspective actually give the influence to the concept of equilibrium price. Although he does not call it as the equilibrium price, but actually the concept of equilibrium price has built in his perspective generally. It also proves that classical Moslem thinker also has influenced the development of economic in the future era.

\section{The Factors Which Is Influence The Equilibrium Price}

There are some factors depend on Ibn Khaldûn's perspective which are influence the equilibrium price, they are: First, The capability of workers and the needed of employer. Ibn

\footnotetext{
${ }^{10}$ Khaldûn, Muqaddimah, 286.

${ }^{11}$ Khaldûn, Muqaddimah, 286.

${ }^{12}$ Iskandar Putong, Pengantar Ekonomi Mikro Dan Makro (Jakarta: Ghalia Indonesia, 2003), 42-43.

${ }^{13}$ Muhamad, Ekonomi Mikro Dalam Perspektif Islam, 361.
}

Jurisdictie: Jurnal Hukum dan Syariah Vol. 6 No. 1 Tahun 2015 
Khaldûn explained that the cause made the price of craft is expensive are, first the quantity of luxury necessity in the city as the impact of the city development, the second is the arrogance of people in doing the work which is available the service because of the easy of having the work in the city. It happen because of there are much main necessity available in the city. The third is there are many rich people who need the service from other people and some creator in their profession. The rich people would take their services and give them more value for their work then other people who want to take their service too, everyone should want to be the worker and craftsman of rich people, because they feel comfortable and they can get the prosperity from that. Then, the price of their service will be expensive. In the other condition, the rich people will be wasteful people to buy the worker service although they should spend much money for it. ${ }^{14}$ The statement bellows explain that the equilibrium price will be happen when there are some interactions of the rich people as the seller to take the service of other people in some works. The price of the worker's service will be cheap when he does not have a good capability in doing his work, and he does not give the satisfied of his employer. But, the price of the worker's service will be expensive when he gives his best capability in doing his work, so his employer will be satisfied with his work. Then, his work will be expensive for the employer because of his work quality.

Second, The condition of city and the population there. The equilibrium price will be different in other condition. When the city is small development of city is low and the population is to little, then the main food is rare, the work available is also rare, the people there will have the thinking that there is no hope there, because of their city is so small, and there is no many main food available. They will have the income just from their hand and they will be heaped up of their goods, then the available of goods is rare for them and the price will be expensive for other people who supply it. For the necessity's facilities or we can say complementary necessity, they will not think about it, because of the population is very little and the economic development is low. So, the impact of it is the goods will not sold, then the price of that goods will be cheap.56 The statement of Ibn Khaldûn before shows that the equilibrium price is also depend on the economic situation in every places. The price of goods in the modern city with high development and many modern population will be different with the village which does not have many population and the economic development is low. Because the capability in selling goods in the modern city is higher than in the village. The people who live in the modern city with good economic development and he has good work, he can survive in his life and his economic ability will be increased, in other situation if the people who live in the village which there is no good economic development, and there is no large work field, they will have low standard of life. Their capacity in buying something also will be low. Then, their prosperity is enough for themselves. In fact, believing or not, the situation of city especially in economic situation give many influences, if the economic condition is good, so the equilibrium price should be kept, and the society can get the goods easily.

Third, The additional cost of goods because of taxation Sometimes in the price of main foods, there some cost burden, such as tax, tributes for the king of markets, in the doors of city, and for the tax collector in taking the benefits determined in the transaction of sell and buying as same as they want. Because of that, the price in the city is more expansive than the price in the village, it happen because of in the village there are no taxation, loads, and obligations, while all of that is very much in the big city, especially when the last of kingdom. ${ }^{15}$ The other factors

\footnotetext{
${ }^{14}$ Khaldûn, Muqaddimah, 286.

${ }^{15}$ Khaldûn, Muqaddimah, 287.

Jurisdictie: Jurnal Hukum dan Syariah Vol. 6 No. 1 Tahun 2015
} 
which is influence the equilibrium price depend on Ibn Khaldun's perspective is the additional cost of goods because of taxation, tributes for king of markets, loads, and other obligation that should be paid by the seller there. It cause the price of goods is very expensive because of the seller does not want to loss, they want to take the profit. The phenomenon will be different in the city or in the village. The cost of taxation and other obligation in the city is upper than the cost in the village. It means that the price of goods because of additional cost in the city is more expensive than in the village. Ibn Khaldûn also identified the role of the state that affects price level through taxation instrument. When government imposes taxes which are light in their rate, but obtain in large revenue, the economy will grow. People will actively get involved in the business and enterprises will develop. People feel that they just give small share of their profit in the form of taxation to the government. On the contrary, when the government start increasing the tax at high rate, the businessmen will be discouraged because they feel that the burden of the tax they must pay is too heavy. Consequently production falls off, and with it the yield of taxation. The rulers may, mistakenly, try to remedy this decrease in the yield of taxation by raising the rate of taxation. Hence, taxes imposed leave no profit for businessmen. This will destroy the economic condition of the country. ${ }^{16}$

Fourth, The political condition in certain place. The thing that also influence the price of goods and the main food is the fee of agriculture management and it influence the price as happened in Andalusia today. It happen because when the Christian pushes them to go to the beach side and the country which is far from the reach of people, the plants is very bad, the plants there also growth badly, then the Christian people take their fertile land, and the good country, so they need the good management in the plants and lands to make good agriculture in their country. The good management would be good if they are some effort which is have the values and some materials to support it, they are fertilizer, and other which is need some fee. In their agriculture there are some needed which are should be shopped, and that needed have risk. Then the effect is the prices in Andalusia becomes expensive since the Christian people push them to go to their crowded region with Islam within their beach. ${ }^{17}$

The explanation is continue by talking about the condition of the population when they listened the increasing price of goods. They think that it happen because of the little of the main foods or the seed. Meanwhile, in the fact the happen is not like that. Actually, they are the people of the wealthy country which they have the biggest agriculture result, and actually there are many expert in that country in agriculture aspect. But, there just a little people who want to work in the land, rich field, or agriculture. Then, it means that the people who manage the agriculture land there are mostly from little craftsman, little service people, or the foreign people who are come to that country and manage the land, the soldier or struggler who is stay there and want to manage the agriculture land there. Because of that the king gives the special place in giving something called 'ulah which is the main foods and 'ulufat or the foods for their animals which comes from the plants. Actually the cause of the expensive of price there is what we have explained before, or it means that it happen because of the fee management especially in agriculture aspect which is become the main work for getting the income and developing the economy in that country.

The other factors which is influence the measure of price is the fee of agriculture management. It happen because in his era, the agriculture becomes the main aspect in developing

\footnotetext{
${ }^{16}$ Irfan Syauqi Beik and Laily Dwi Arsyianti, "IBN Khaldun's Contribution on Modern Economic Development: An Analysis Based on Selected Economic Issues," JURNAL EKONOMI DAN KEBIJAKAN PEMBANGUNAN 1, no. 2 (2008): 8, http://journal.ipb.ac.id/index.php/jekp/article/view/4508.

${ }^{17}$ Khaldûn, Muqaddimah, 287.

Jurisdictie: Jurnal Hukum dan Syariah Vol. 6 No. 1 Tahun 2015
} 
economy, then the price of goods also can be depend to the fee which is used for manage the main materials. Ibn Khaldûn gives the example is the reality happen when the Christian people stayed in Andalusia. They stayed as the colony of Andalusia which is use their power to pushes the Andalusian people to work hard in managing the land and agriculture land. So, the colony takes the society's capability in agriculture and push them with their power. Then, the prices of good and main necessity is very expensive. The phenomenon of society who want to manage the land is happen, they are so little people who want to manage it. Then, the management of agriculture is taken by the some foreign agriculture expert, little craftsman, little service people, or the foreign people who are come to that country and manage the land, the soldier or struggler who is stay there and want to manage the agriculture land there. In the other side, the Barbarian countries does not have the burden in fee for developing their agriculture land, they have good plants, good lands, and good management of agriculture which is does not had by the other countries.

Then, the fee for agriculture is nothing or it can be very little, within the same distribution of that plants rise. So, it becomes the impact of the decreasing price or it can be the price of goods is relatively cheap in that country. ${ }^{18}$ The explanation bellows is about the different price in land of colonization like as Andalusia and the Barbarian land which is have the truly freedom. The price in the colonization land is relatively expensive, because in that land the colony powered all of the plants or agriculture land which is have good fertilizer and good for planting some profitable plants. But, in fact the people who live around the that area should be pushed by the colonization country. In the other side, the Barbarian will have good prosperity in managing the agriculture land, they are the free from colonization, they are free society. They have the freedom for managing their land by themselves. They can planting some plants as they want, they can cut it every time they want, they also can pick it whenever they want. They do not give much money to manage their agriculture land, because of they have good land and good management for developing it. So, it is possible to them for making the price of goods from their agriculture land becomes cheaper than the plants in the colonization land. ${ }^{19}$

Fifth, The understanding of trader about the taste of buyers. The other factor of equilibrium price explained by Ibn Khaldûn in Muqaddimah book in the special part with the title "Commodity Export and Import in The Trading Process". This part explained generally about the international trading in Ibn Khaldûn's era. The professional trader will not move the trading commodity if it is not needed enough. Sometimes, the commodity of goods is need by several society, such as rich person, poor person, the power society, or others. Because with this condition, the possibility of supply will be developed in one of commodity. But, if the commodity is needed by some certain society, so the increasing of value and price will be impossible to reach it. Because the trader will face the difficulties in sell the commodity. It happen because of the ability for buying it just kept by some society, so the impact is the weakness of market and it can damage the profit of the seller. ${ }^{20}$ The explanation in that statement told about equilibrium price when the export and import of trading is happen, the price will be stabile when the commodity of goods is needed very much by several society such as rich person, poor person, the power society, or others. Because it can be possible if the selling of goods will be increased. So, the equilibrium price will be reached when the trader and the buyer agree to do the transaction and exchange money with the goods needed. In the other hand, the trader will face

\footnotetext{
${ }^{18}$ Khaldûn, Muqaddimah, 287.

${ }^{19}$ Khaldûn, Muqaddimah, 287.

${ }^{20}$ Khaldûn, Muqaddimah, 312.

Jurisdictie: Jurnal Hukum dan Syariah Vol. 6 No. 1 Tahun 2015
} 
the difficulties in selling the goods when the people who need the commodity is very little. Then the possibility of reaching the equilibrium price is very little.

The other factor which is influence the equilibrium price is the capacity of trader in choosing the quality of goods. From the reality bellows, the society will think more about the middle quality of goods, because the middle quality of goods is mostly attracted all of the society, because it is suitable to most of the society, such as rich person, poor person, the power society, or others, and the best quality of commodity just for the power society. Because of that, the trader should give their capability to choose the quantity of goods, because their capability in doing it can be entrusted to the value of goods and it price will be increased or it will be decreased. ${ }^{21}$ The explanation of that statement is the capacity of trader in choosing the quality of goods will influence the equilibrium price will be reached or not. It also related to the capacity of trader in understanding about the condition of necessity needed in that place within understanding to the society condition in that place.

Sixth, The distance and the challenge faced by the trader. The next factor of equilibrium price is the distance in sending of commodity to other country. If the distance is far or should across to the dangerous which is threatened will make the commodity more have the value and the price will be high, then it can give the much profit for the seller and it can guarantee the market stability. Because the number of export commodity is actually little and it is very needed by the society because of the distance of the place and the dangerous cross of that. The other impact of it is the people want to bring it is very little and the goods is rarely available. If the number of commodity is very little and rare in the market, so the price will be expensive. Beside that, if the commodity comes from the place or kingdom which is located in the near distance and there is the easy to reach that region, because of its safety so the people who will send the goods will be much, then the commodity will collected in the market, so the price of it will be decreased. $^{22}$

In this part, Ibn Khaldûn explain about the distance and the level of challenge which is faced by the trader will influence the price too. The price of goods will be cheap when the distance between the country of trader to the country purposed is near. In opposite, the price will be expensive when the distance of the country of trader to the country purposed is far. The challenge in the cross of the trader also influence the price of goods. If the challenge which crossed by the trader is so dangerous, the price will be expensive, but if the road of the trader in bringing the goods is safety enough then the price of goods will be cheap enough too. After that, Ibn Khaldûn gives the example of the concept bellows by showing the condition in his country. He said that "You can see about the trader who enter to the Sudan kingdom, they become the richer man and they have much wealthy today because of their heavy struggle and the big challenge of his road in bringing the goods.

The trader should cross to the dangerous road which is difficult to pass on it, the dangerous which threatened every time such as afraid, thirsty because of there are no enough water. And to get the water they should look for it with the leader of group there until there are no people who want to cross that way, the people who want do it is very little." Because of the condition which is explained by Ibn Khaldûn before, he conclude that the commodity of trading of Sudan is very little in his country, then the price of commodity in that country is very expensive, in the opposite the goods commodity of his country also little in Sudan, so the price of it will be expensive. The trader who is brave to pass on the heavy road will get the much commodity and they also can get

\footnotetext{
${ }^{21}$ Khaldûn, Muqaddimah, 312.

${ }^{22}$ Khaldûn, Muqaddimah, 312.

Jurisdictie: Jurnal Hukum dan Syariah Vol. 6 No. 1 Tahun 2015
} 
the much wealthy, then it can make him to be rich person in that country. It also happen to the people who do the walking to the east country will have the wealthy, and becomes the rich person because of their spirit and effort for them. Meanwhile, the trader who stayed in the certain place, such in their region or in their country, they will have effort for income of the trader, because the income will be little because of the many number of commodity, and the people who is want to send it is much in that certain region. ${ }^{23}$

That condition of development of live which is should be begun, the trading system also have an occasion to develop. In the beginning of trading process in that era, the trader just sell their goods around there area, without knowing the situation in other country which is actually will give the profit more than just trading in a certain area. The equilibrium price concept will happen there if the suitable price wanted by the seller and buyer is determined. As we explain before that if the trader walk on the dangerous cross and there are so many challenge the price of goods will be expensive. In the other situation, if the trader does not walk on the dangerous cross and he does not face the challenge for doing the trading, so the price of goods will be cheap. It is all depend on the condition of the road crossed by the trader.

Seventh, Monopoly Practice Ibn Khaldûn also explain about monopoly which can influence the equilibrium price in the market. He explained it in the certain title "Monopoly". He told that actually the big problem of trading in the country is collecting the commodity and after that the collector will sell it when the condition of market is very need to that commodity. Then, the price of that good will be expensive. That action is very bad and the profit gotten will be loss easily. ${ }^{24}$ It is because of when the society need the commodity, so they will give all of their money to get it. When the condition is like that, the certain people do monopoly until the soul of the society will be bad. Their soul is related to their wealth, they will not calm in their life, then for who take their commodity will have disaster, and their life will be sad. Actually in this part Ibn Khaldûn told the reader about the condition of the price in the economic situation of his era. He explained by the good arrangement of story. In the beginning of this part, he explained about the meaning of the monopoly generally, after that he critics about the bad action namely monopoly practice which is done by everyone who collect the commodity needed in the market. Without taking care to other right of people about that commodity.

Ibn Khaldûn makes sure that the action bellows is bad action and Allah dislikes that. The monopoly action influences the equilibrium price, because if the monopoly practice done in the market and the people there should need the commodity collected, then the society there can not get their necessity needed easily. Of course, it becomes the burden to all of the society in their life exactly. Because of that the price of the commodity will be very expensive. Ibn Khaldûn closes this part by told a story from Abdullah al- Ubuli. Abdullah al- Ubuli said that "one day, I come to the court in front of the judged in Fez in the era of Abu Sa'id exactly, namely Abu alHusain al- Malili, one of the expert of Islamic law. He demanded to chose about from where his fee should be paid, after that he answered "from the retribution of alcohol". After that, his friends which are come to their place feel surprised and laughed when listen his told. Then, they asked to him about the value of and the benefit of that situation. ${ }^{25}$

Because of hearing that, then Abu Hasan al- Malili gives the answer of that question " If all of the retribution is forbidden, I will chose the retribution which everyone want to give it to other people. Alcohol is actually the forbidden commodity, and there are not many people who want to

\footnotetext{
${ }^{23}$ Khaldûn, Muqaddimah, 312.

${ }^{24}$ Khaldûn, Muqaddimah, 312.

${ }^{25}$ Khaldûn, Muqaddimah, 312.

Jurisdictie: Jurnal Hukum dan Syariah Vol. 6 No. 1 Tahun 2015
} 
get it with the money except they like it very much, or there is no burden to get it, and their soul are not related to their wealth." 26 The story bellows told the reader about the important of the willingness of other people in giving their goods. The judge shows us that actually having the willingness of other people in taking his goods is very important because the willingness is one of the reason to get the good benefits of everything that is given to other people. In the framework of monopoly, the main point of the statement is actually monopoly is collecting the commodity needed by the most of people to take much profit when the collector sell it in the bad market situation which is all of the people look for it and want to get it. Actually the actor do the big false in doing that action, because believe or not, the in the commodity collected by him, there are so many rights of other people inside of it which is taken by him cruelly without knowing to other people condition. Of course, the people who have the right in that commodity will not have the willingness to the collector of their commodity needed.

Because of they should buy the commodity with more expensive price. In that situation the equilibrium price will not be happen because of there is no the balancing in that trading practice. It has been known that actually monopoly is forbidden in Islam because of this action will give the burden to every people who want to get the goods easily, but because of the burden which is come from that monopoly, so the people who need the product, especially main food should look for it hardly, and he can get by paying much money. Eighth, The prosperity of the population In the specific title " The Province Region Has The Various of The Prosperity As The Town" in this part, Ibn Khaldûn told about the phenomenon happen when the city is developed, then the necessity of the population there is very much because of the luxurious of the society there. The fee or income of worker there is higher than other region, but the complementary goods can be the main necessity. Beside that as long as the time spent the work in the city becomes rare, the price of all facilities becomes expensive, to get the facilities all of people there will snatch away to each other, then the price of product in there becomes expensive. ${ }^{27}$ In additional aspect, there are so many burden fee that should be paid by the society, such as taxation and others, the burden for getting the luxurious goods also influence the prosperity life in the city. Because of many shopping they do, the outcome of the population is too much in the city as same as the development of city. In that situation the people in the city also need the wealth very much to get the necessity they wanted.

The city society will have the high lifestyle and keep effort to get it. In the opposite condition, Ibn Khaldûn also explain about the different situation which is happen in Barbarian area. Actually the income of the Barbarian is very little, because they stay in the place where the markets of work which can given the income is not sold. They can not product the income or the goods needed, then it becomes the impact for them because of they feel difficult to stay in the modern city where the price of all fasilities are expensive, and the necessity is rare. Meanwhile, in the Bedouin area, they can get their necessity within give the little work, because they do not have the luxurious lifestyle and the cost of life in their region is little. Every Bedouin people who stayed in the big city will feel bored, and his life will be bad. But, if they can survive to stay in the modern city within they can product the wealthy more than they need before, so in that time they can move and survive to stay in the modern city with the various luxury and the luxurious lifestyle of the population there. ${ }^{28}$ In this explanation, Ibn Khaldûn shown that the prosperity aspect depend on the wealthy of someone is also can influence the equilibrium there. The

\footnotetext{
${ }^{26}$ Khaldûn, Muqaddimah, 312.

${ }^{27}$ Khaldûn, Muqaddimah, 287.

${ }^{28}$ Khaldûn, Muqaddimah, 287-288.

Jurisdictie: Jurnal Hukum dan Syariah Vol. 6 No. 1 Tahun 2015
} 
phenomenon as the story bellows give many shape of the condition of the society in Ibn Khaldûn's era. The population in the city who need many luxurious necessity will pay for it, because their income is higher than the village population, so the pprice of goods in that area shoul be expensive and to get it every people should have the really effort because the other people in that city also want to take that goods.

In the other side, the lifestyle of Bedouin taught the reader to have the simple life in the area which does show the luxurious life, with the population who want to have the simple life. They will not be worry to complete their necessity. Because of they do not have the willing to buy the luxurious goods like as the people of city want to do. Although, their income is so little, but they can complete their necessity by themselves without needing to the luxurious goods. Then, the price of goods there will be cheap. ${ }^{29}$ About the prosperity side, Ibn Khaldûn explain it more in the different title "The District Area Has The Differences In The Prosperity And Poverty Same As The Town". Ibn Khaldûn explains in this part about the situation of the district area, which has the good development. If the district has good development and the economic condition also have good development, then the prosperity of population will be increased.

\section{The Similarities and The Differences Between Ibn Khaldûn's Equilibrium of Price and Contemporary Equilibrium of Price}

The Similarities Between Ibn Khaldûn's Equilibrium of Price and Contemporary Equilibrium of Price The contemporary perspective about equilibrium of price which was built by Adam Smith in "Wealth of Nation" book. The market price of every particular commodity is regulated by the proportion between the quantity which is actually brought to market, and the demand of those who are willing to pay the natural price of the commodity, or the whole value of the rent, labour, and profit, which must be paid in order to bring it thither. Such people may be called the effectual demanders, and their demand the effectual demand; since it may be sufficient to effectuate the bringing of the commodity to market. It is different from the absolute demand. A very poor man may be said, in some sense, to have a demand for a coach and six; he might like to have it; but his demand is not an effectual demand, as the commodity can never be brought to market in order to satisfy it. ${ }^{30}$ The first similarity between the concept of equilibrium of price from Ibn Khaldûn and Adam Smith is about the situation of happening of equilibrium price, that is when the quantity of commodity as same as the demand of buyers.

When the quantity of any commodity which is brought to market falls short of the effectual demand, all those who are willing to pay the whole value of the rent, wages, and profit, which must be paid in order to bring it thither, cannot be supplied with the quantity which they want. Rather than want it altogether, some of them will be willing to give more. A competition will immediately begin among them, and the market price will rise more or less above the natural price, according as either the greatness of the deficiency, or the wealth and wanton luxury of the competitors, happen to animate more or less the eagerness of the competition. ${ }^{31}$ Second similarity is about the situation when the available of commodity is not enough for completing the demand, so the price will be expensive. Among competitors of equal wealth and luxury, the same deficiency will generally occasion a more or less eager competition, according as the acquisition of the commodity happens to be of more or less importance to them. Hence the exorbitant price

\footnotetext{
${ }^{29}$ Khaldûn, Muqaddimah, 287-288.

${ }^{30}$ Adam Smith, An Inquiry into the Nature and Causes of the Wealth of Nations (Pennsylvania: Electronic Classics Series, 2014), 52.

${ }^{31}$ Smith, An Inquiry into the Nature, 52.

Jurisdictie: Jurnal Hukum dan Syariah Vol. 6 No. 1 Tahun 2015
} 
of the necessaries of life during the blockade of a town, or in a famine. When the quantity brought to market exceeds the effectual demand, it cannot be all sold to those who are willing to pay the whole value of the rent, wages, and profit, which must be paid in order to bring it thither. Some part must be sold to those who are willing to pay less, and the low price which they give for it must reduce the price of the whole.

The market price will sink more or less below the natural price, according as the greatness of the excess increases more or less the competition of the sellers, or according as it happens to be more or less important to them to get immediately rid of the commodity. The same excess in the importation of perishable, will occasion a much greater competition than in that of durable commodities; in the importation of oranges, for example, than in that of old iron. ${ }^{32}$ Third is about the condition when the available of commodity is more than the demand, so the commodity will not be sold all, then the seller should decrease the price to the lower price. When the quantity brought to market is just sufficient to supply the effectual demand, and no more, the market price naturally comes to be either exactly, or as nearly as can be judged of, the same with the natural price. The whole quantity upon hand can be disposed of for this price, and can not be disposed of for more. The competition of the different dealers obliges them all to accept of this price, but does not oblige them to accept of less. The quantity of every commodity brought to market naturally suits itself to the effectual demand. It is the interest of all those who employ their land, labour, or stock, in bringing any commodity to market, that the quantity never should exceed the effectual demand; and it is the interest of all other people that it never should fall short of that demand. ${ }^{33}$

The fourth is about the condition when the quantity of available commodity is same as the quantity of demand, and no more. So, the equilibrium of price can be implemented. If at any time it exceeds the effectual demand, some of the component parts of its price must be paid below their natural rate. If it is rent, the interest of the landlords will immediately prompt them to withdraw a part of their land; and if it is wages or profit, the interest of the labourers in the one case, and of their employers in the other, will prompt them to withdraw a part of their labour or stock, from this employment. The quantity brought to market will soon be no more than sufficient to supply the effectual demand. All the different parts of its price will rise to their natural rate, and the whole price to its natural price. If, on the contrary, the quantity brought to market should at any time fall short of the effectual demand, some of the component parts of its price must rise above their natural rate. If it is rent, the interest of all other landlords will naturally prompt them to prepare more land for the raising of this commodity; if it is wages or profit, the interest of all other labourers and dealers will soon prompt them to employ more labour and stock in preparing and bringing it to market. ${ }^{34}$ Beside the concept from Adam Smith, Alfred Marshall also give the concept about the supply and demand which are have the similarities with Ibn Khaldûn 's concept. Alfred Marshall as the creator of demand law which has the meaning that if the price of a commodity is increase, then the demand of commodity will be decreased, in opposite if the price of that commodity is decrease, so the demand will be increased.77 Alfred Marshall also creates the supply law it is the straight line between the price and the quantity of commodity supplied, that is when the price is increase, then the demand will be increased too, but when the price is decrease, the demand also will be decreased. ${ }^{35}$

\footnotetext{
${ }^{32}$ Smith, An Inquiry into the Nature, 52.

${ }^{33}$ Smith, An Inquiry into the Nature, 53.

${ }^{34}$ Putong, Pengantar Ekonomi Mikro Dan Makro, 33.

${ }^{35}$ Putong, Pengantar Ekonomi Mikro Dan Makro, 38.

Jurisdictie: Jurnal Hukum dan Syariah Vol. 6 No. 1 Tahun 2015
} 
The differences between Ibn Khaldûn 's equilibrium of price and contemporary equilibrium of price From the analyzing of Ibn Khaldûn 's concept about equilibrium of price, actually the general concept of Ibn Khaldûn as same as the general concept of equilibrium of price from Adam Smith. Beside that, Alfred Marshall's concept about supply and demand are not too far from Ibn Khaldûn 's concept. But, in the development of Islamic economy, the modern Islamic scholar limit the commodity traded with some provisions. Such as the provision about the allowed commodity which can be sold. As long as the analyzing of the writer, from the examples which are taken by Ibn Khaldûn are around the staple food, like as wheat flour, and some primary necessity like as clothes, and secondary necessity like as side dish. On behalf of his explanation, the writer conclude that actually Ibn Khaldûn intimates the allowed commodity for selling depend on Islamic law provision generally. Beside that, in some explanations Ibn Khaldûn also related the equilibrium of price with the social economy condition. Because, in fact the wealth of person will influence the measure of his necessity. The rich person will have many necessity to be completed, because of they have a high lifestyle. Ibn Khaldûn remind that everyone should limited their necessity, because Islam forbid wasting action.

\section{Conclusion}

The equilibrium price happen in Ibn Khaldûn 's era depend on his explanation in Muqaddimah book when the quantity of demand as same as the quantity of supply of goods. It is related to the available of goods, and the situation of development of city. It also become the concept in the economic modern when the supply and demand of product should influence to the equilibrium of price. The conclusion about Ibn Khaldûn 's perspective about the factors which influence the equilibrium price. (a) The capability of workers and the needed of employer; (b) The condition of city and the population there; (c) The additional cost of goods because of taxation; (d) The political condition in certain place; (e) The understanding of trader about the taste of buyers; (f) The distance and the challenge faced by the trader; (g) The prosperity of the population; (h) The similarities and the differences between Ibn Khaldûn 's equilibrium of price and contempore equilibrium of price.

The similarities between them are general concept of equilibrium of price and the concept of supply and demand as the explanations below: (a) The similarity between the concept of equilibrium of price from Ibn Khaldûn and Adam Smith is about the situation of happening of equilibrium price, that is when the quantity of commodity as same as the demand of buyers; (b) The similarity about the situation when the available of commodity is not enough for completing the demand, so the price will be expensive; (c) The similarity about the condition when the available of commodity is more than the demand, so the commodity will not be sold all, then the seller should decrease the price to the lower price; (d) The similarity about the condition when the quantity of available commodity is same as the quantity of demand, and no more. So, the equilibrium of price can be implemented. Beside the similarities, there are also some differences between Ibn Khaldûn 's equilibrium of price and contemporary equilibrium of price, it is around the allowed commodity which can be sold depend on Islamic law and western perspective is different. Beside that, the different between them shown especially about the remind of limitation of necessity for every people. The contemporary or western equilibrium of price perspective does not explain about the limitation of necessity for every people. 


\section{Bibliography}

Ali, Zainuddin. Metode Penelitian Hukum. Jakarta: Sinar Grafika, 2011.

Beik, Irfan Syauqi, and Laily Dwi Arsyianti. "IBN Khaldun's Contribution on Modern Economic

Development: An Analysis Based on Selected Economic Issues." JURNAL EKONOMI

DAN KEBIJAKAN PEMBANGUNAN 1, no. 2 (2008).

http://journal.ipb.ac.id/index.php/jekp/article/view/4508.

Deliarnov. Perkembangan Pemikiran Ekonomi. Jakarta: Raja Grafindo Persada, 2007.

Khaldûn, Ibn. Muqaddimah Ibn Khaldûn. Beirut: Dâr al- Kutub al-'Ilmiyyah, 2009.

Moleong, Lexy J. Metodologi Penelitian Kualitatif. Bandung: Remaja Rosdakarya, 2011.

Muhamad. Ekonomi Mikro Dalam Perspektif Islam. Yogyakarta: BPFE-Yogyakarta, 2004.

Narbuko, Cholid, and Abu Achmadi. Metodologi Penelitian. Jakarta: Bumi Aksara, 2003.

Putong, Iskandar. Pengantar Ekonomi Mikro Dan Makro. Jakarta: Ghalia Indonesia, 2003.

Rusydiana, Aam Slamet, Muhamad Jarkasih, Mahbubi Ali, Luthfillah Habibi, and Abdussalam. Ekonomi Islam Subtantif. Bogor: Gaung Persada Press, 2009.

Smith, Adam. An Inquiry into the Nature and Causes of the Wealth of Nations. Pennsylvania: Electronic Classics Series, 2014. 